\title{
Combining systems biology models of apoptosis provides superior predictions of the responsiveness of melanoma cells to cell death inducing drugs
}

\author{
Paul Curtayne ${ }^{1 *}$, Maximilian Wuerstle ${ }^{2}$, Andreas Lindner ${ }^{2}$, Jochen Prehn², Markus Rehm² \\ From 4th International Conference for Healthcare and Medical Students (ICHAMS) 2014 \\ Dublin, Ireland. 24-25 October 2014
}

\section{Background}

Key to the clinical management of melanoma is the development of new diagnostic tools that predict individual patient prognosis and select from potential treatments those which may be effective. Identifying individual biomarkers in tumour cells to predict susceptibility to apoptotic cell death has thus far been largely unsuccessful, as apoptosis pathways show a high degree of signalling redundancy.

\section{Methods}

DR_MOMP [1] and ApoptoCell [2] are mathematical systems biology models of the mitochondrial outer membrane permeabilisation and execution stages of the apoptosis pathway, respectively, that take into account the complex nature of apoptosis regulation. Both models use a network of ordinary differential equations representing measured protein concentrations and reaction kinetics. In this study we combine these models and compare model predictions to experimental measurements of cell death in a range of melanoma cell-lines that were treated with different cytotoxic agents.

\section{Results}

The combined approach is found to outperform either individual model in predicting strong and weak responses to treatment with cell death inducing drugs.

\section{Conclusions}

This work may provide a basis for the development of improved prediction tools for clinical treatment outcomes and treatment selection in melanoma.

${ }^{1}$ Royal College of Surgeons in Ireland, Dublin, Ireland

Full list of author information is available at the end of the article

\section{Authors' details}

${ }^{1}$ Royal College of Surgeons in Ireland, Dublin, Ireland. ${ }^{2}$ Centre for Systems Medicine, Dept of Physiology and Medical Physics, Royal College of

Surgeons in Ireland. Dublin, Ireland.

Published: 27 October 2015

References

1. Lindner AU, Concannon CG, Boukes GJ, Cannon MD, Llambi F, Ryan D, et al: Systems Analysis of BCL2 Protein Family Interactions Establishes a Model to Predict Responses to Chemotherapy. Cancer Research 2013, 73(2):519-28.

2. Rehm M, Huber HJ, Dussmann H, Prehn JHM: Systems analysis of effector caspase activation and its control by $\mathrm{X}$-linked inhibitor of apoptosis protein. EMBO J. $2520064338-49$.

doi:10.1186/1753-6561-9-S7-A10

Cite this article as: Curtayne et al:: Combining systems biology models of apoptosis provides superior predictions of the responsiveness of melanoma cells to cell death inducing drugs. BMC Proceedings 2015 9(Suppl 7):A10.
Submit your next manuscript to BioMed Central and take full advantage of:

- Convenient online submission

- Thorough peer review

- No space constraints or color figure charges

- Immediate publication on acceptance

- Inclusion in PubMed, CAS, Scopus and Google Scholar

- Research which is freely available for redistribution
C Biomed Central 